\title{
THE NON-IMPLEMENTATION OF THE NURSING PROCESS: REFLECTION BASED ON DELEUZE'S AND GUATTARI'S CONCEPTS
}

\author{
Paula Pereira de Figueiredo ${ }^{1}$, Wilson Danilo Lunardi Filho ${ }^{2}$, Rosemary Silva da Silveira ${ }^{3}$, Adriana Dora da \\ Fonseca ${ }^{4}$
}

\footnotetext{
${ }^{1}$ Ph.D. in Nursing. Professor at the School of Nursing at the Universidade Federal do Rio Grande (FURG). Rio Grande, Rio Grande do Sul, Brazil. E-mail: paulafigueiredo@furg.br.

${ }^{2}$ Ph.D. in Nursing. Professor at the School of Nursing at FURG. Rio Grande, Rio Grande do Sul, Brazil. E-mail: lunardifilho@ terra.com.br

${ }^{3}$ Ph.D. in Nursing. Professor at the School of Nursing at FURG. Rio Grande, Rio Grande do Sul, Brazil. E-mail: anacarol@ mikrus.com.br

${ }^{4}$ Ph.D. in Nursing. Professor at the School of Nursing at FURG. Rio Grande, Rio Grande do Sul, Brazil. E-mail: adriana@ vetorialnet.com.br
}

\begin{abstract}
The nursing process can contribute to consolidate nursing as a science, as it evidences the systematization of its thinking and its actions, providing visibility to the work that is done. However, national and international studies have reported many difficulties that are faced when implementing it. These difficulties motivated the development of this study, which had the objective of discussing and reflecting on nursing work from a theoretical revision supported by aspects of subjectivity according to Deleuze and Guattari, considering that they may be unconsciously expressed by nurses in their daily professional tasks, resulting in the non-implementation of the nursing process.
\end{abstract}

DESCRIPTORS: Nursing process. Work. Nursing.

\section{A NÃO IMPLEMENTAÇÃO DO PROCESSO DE ENFERMAGEM: REFLEXÃO APOIADA EM CONCEITOS DE DELEUZE E GUATTARI}

RESUMO: O processo de enfermagem pode contribuir para a consolidação da enfermagem como ciência, já que explicita a sistematização do seu pensar e do seu fazer, proporcionando visibilidade ao trabalho que é realizado. Entretanto, há muitas dificuldades de implementálo, relatadas em estudos nacionais e internacionais. Essas dificuldades motivaram a realização desse estudo, que teve como objetivo discutir e refletir sobre o trabalho da enfermagem, a partir de revisão teórica apoiada em aspectos da subjetividade, segundo Deleuze e Guattari, tendo em vista que podem ser inconscientemente manifestados pelas enfermeiras no seu cotidiano profissional, resultando na não implementação do processo de enfermagem.

DESCRITORES: Processos de enfermagem. Trabalho. Enfermagem.

\section{LA NO IMPLANTACIÓN DEL PROCESO DE ENFERMERÍA: REFLEXIÓN APOYADA EN CONCEPTOS DE DELEUZE Y GUATTARI}

RESUMEN: El proceso de enfermería se constituye una fortaleza en la ciencia de Enfermería, pues contribuye para su consolidación, ya que explicita la sistematización del su pensar y hacer, dando visibilidad al trabajo que es realizado. Todavía, hay muchas dificultades en su implementación, reportadas en estudios nacionales e internacionales. Esas dificultades han motivado la construcción de este texto, que tuvo por objetivo reflexionar acerca del trabajo de enfermería, a partir de una reflexión teórica apoyada en aspectos de la subjetividad, de acuerdo con Deleuze y Guattari, llevando en cuenta que ellos pueden ser inconscientemente expresados por las enfermeras en su trabajo diario, afectando la implementación del proceso de enfermería.

DESCRIPTORES: Procesos de enfermería. Trabajo. Enfermería. 


\section{INTRODUCTION}

The nursing process (NP) has become a fortress in the science of nursing and is considered an instrument that enables the planning and development of qualified care for the individual, family, and community, as well as a record of the professional practice. ${ }^{1}$ It can also be considered a methodological model that helps identify, understand, describe, explain, or predict human health needs of those who receive nursing care ${ }^{2}$ because it favors safe decision-making in various clinical situations, decreases care fragmentation, and ensures its continuity, even serving as a permanent foundation for nursing education, research, and management.

Therefore, the NP can reinforce critical thinking, promote a clinical and investigative reasoning, and foster the continuous search for information aimed at obtaining scientific evidence. ${ }^{3}$ By combining these characteristics, it reflects the commitment of nurses to the client under their care and their engagement with meeting and satisfying the human health needs affected.

Beyond these more general concepts, it is worth noting that the NP can contribute to consolidate nursing as a science, as it evidences the systematization of its thinking and actions and provides visibility to the work that is done from its own perspective, the perspective of the other professionals that make up the nursing/healthcare team, as well as of the individual and/or collective subjects who are cared for. In Brazil, its implementation is mandatory as per resolution n. 358/2009 of the Federal Board of Nursing (COFEN), which proposes it to be implemented in five interrelated, interdependent, and recurring stages: 1) Data collection of nursing (nursing history), 2) Nursing diagnosis, 3) Nursing planning, 4) Implementation, and 5) Nursing evaluation. ${ }^{4}$

However, despite this regulation and its importance, denials and difficulties in its implementation are still found, which are attributed to factors such as the difference between theory and practice, the lack of time of the professionals, the lack of instruments for nurses to do their job, the accumulation of activities in the environments of care, deviations from the function, the low perception of the nursing workers about the impact of the NP on the organization of their work and on the quality of care, along with the lack of nurses in inpatient units, disbelief, individualized resistance, and weakness in the training during gradu- ation. ${ }^{2-3,5-6}$ Internationally, the reasons pointed out for explaining the non-implementation of the NP have been lack of time due to high workloads, lack of human and material resources, lack of instruments for their operation, refusal of professionals, and need for continuous training of nurses. ${ }^{7}$

In Finland, the obstacles to using nursing diagnoses can be represented by a lack of motivation, lack of sufficient information about them, time constraints, resistance from older nurses or lack of capacity or power to make changes, resistance from doctors and assistants, and due to the fact that they consider the classification not to be useful or understandable to the nurses themselves. ${ }^{8}$ As regards the implementation and maintenance of individual care plans, a study developed in Sweden highlights a significant difference between what is recommended in nursing legislation and what is done in practice. So, as it seems, even in exemplary first-world countries the implementation of all stages of the NP has also been deficient and/or not prioritized. ${ }^{9}$

Thus, it could be considered that certain characteristic behaviors reproduced in most health institutions, especially in hospitals, are the result of the heterogeneous composition of the teams composing them, whether they are managers, physicians, nurses, or other healthcare workers. Each team, in turn, is made up of individual subjects who have knowledge, beliefs, values, and attitudes, historically and socially constructed, that are incorporated into the subjectivity that express themselves, consciously or unconsciously, in their way of working. Because of this, it is necessary to go deeper into the concept of subjectivity in order to discuss and reflect on nursing, and this way, as we identify how this subjectivity is produced, it will be possible to get beyond the naive curiosity that pervades the reasons why the NP is not implemented and move toward generating new knowledge.

Therefore, it is relevant to discuss and reflect more deeply on the work of nursing and the possible aspects that might influence it so that the implementation of the NP is not harmed or even made impracticable. To this end, a process was adopted supported on the philosophical framework of Deleuze and Guattari, which is based on the concepts of rhizome and the tree and incorporates aspects of subjectivity for explaining capitalistic phenomena that influence all sectors of social production, including nursing/health work. The objective of this study, therefore, is to discuss and 
reflect on nursing work from a theoretical revision supported by aspects of subjectivity, considering that they may be unconsciously expressed by nurses in their daily professional tasks, resulting in the non-implementation of the nursing process.

\section{SUBJECTIVITY AND ITS PRODUCTION FROM THE PERSPECTIVE OF DELEUZE AND GUATTARI}

Before reflecting on nursing work from the perspective proposed, it is necessary to address conceptually what it is and how subjectivity is produced, as this will make it possible to think beyond the difficulties of implementing the NP by the implementation of all of its stages. The theoretical basis seeks to provide elements for discussion and reflection on aspects that have not yet been considered, and it also makes it possible to go deeper into the reasons reported in literature for not implementing the NP.

For Deleuze and Guattari, subjectivity is the industrial, machinic nature, which is essentially fabricated, modeled, received, consumed. ${ }^{10}$ "The subjectification processes are not centered on individual agents (the functioning of intrapsychic, egoic, micro-social instances) nor on group agents. These processes are doubly displaced. They imply in the operation of machinery of expression that can be either of an extrapersonal, extraindividual nature (machinic, economic, social, technological, iconic, ecological, ethological, or media systems, which are no longer immediately anthropological systems), or of a subhuman, infrapsychic, infrapersonal nature (systems of perception, sensitivity, affection, desire, representation, image, and value, ways of memorization and producing ideas, inhibition systems and of automatism, as well as body, organic, biological, and physiological systems, and so on)." 10:39

Thus, subjectivity seems to be characterized in a twofold manner: on the one hand, the fact of inhabiting infra-personal processes and on the other, the fact that it is essentially negotiated at a level of social, economic, and machinic relations, of being open to all socio-anthropological and economic determinations. In short, there are three characteristics of subjectivity: 1) not being subject to totalization or centralization on the individual since it is essentially fabricated and modeled in the registration of the social; 2 ) being essentially social, assumed and experienced by individuals in their private existences; and 3) being manufactured like energy, electricity, or aluminum. ${ }^{10}$

Subjectivity is therefore plural and can be built internally or externally. With regard to workers, their subjectivity has been built from childhood based on the family and school, and follows them throughout life, always striving to meet the demands imposed by capitalism. This subjectivity, called capitalistic subjectivity, can be unconsciously built by social equipment (religious, military, and corporate institutions, etc.), by the media, and by the psychological methods of adaptation of all types, including the relations of ruling power. The function of this capitalistic subjectivity is to cause people to get into preset frames so as to adapt them to supposedly universal and eternal purposes, which may be contrary to their interests. ${ }^{10-11}$

Thus, capitalistic subjectivity turns out to be naturalized in individuals so that they can unconsciously become accomplices of dominant repressive formations that lead them to also participate in the production of control and repression. Obeying this system may be related to the acceptance that this is the only possible system, because otherwise, if this order is disobeyed, then society's organization could be compromised. Therefore, obedience to authority is embedded into the human behavior and is historically and socially constructed. The change in this condition, however, depends on the emergence of the desire to disobey, which is typically perceived as dangerous and asocial and out of the system's standards. ${ }^{10-11}$

Exactly because of the conceptions built over the social and individual trajectory, confronting the oppressive conditions is generally repressed by both the system and by the individuals, which means that they themselves boycott their desire to do things differently, to create, and to release. It can be argued, therefore, that we are collaborators with the production of a childlike subjectivity that establishes a relation of dependence on the state, which tends to be the mediator of everything that is done and what is thought, or what might be done or thought, meaning that the state becomes the mediator of any social production. ${ }^{10-11}$

This attitude can also be explained by the fear we have to be confined to marginality, meaning that we are transformed into "marginal people" (outcasts), and as such become victims of greater control, scrutiny, and punishment, even to the point of having our very possibility of survival endangered. In this case, then, the tendency is to take on a merely defensive position, even if it goes 
against our ideals and conscience.

The way in which individuals live subjectivity oscillates between two extremes: a relation of alienation and oppression in which individuals submit themselves to subjectivity as they receive it, as it has already been highlighted; or then a relationship of expression and creation in which individuals take on again the components of subjectivity, producing a process that is called singularization, meaning, "something that frustrates these mechanisms of internalization of capitalistic values, something that can lead to the affirmation of values in a particular registration regardless of the levels of value that surround us and lurk from all sides."10:55

What will characterize this process of singularization of the worker is that it is self-molding. This means that it captures the elements of the situation, that it builds its own kinds of practical and theoretical references without being in a position of constant dependence in relation to the global power at an economic, knowledge and technical level, and at the level of segregations, of the types of prestige that are widespread. From the moment that the individuals and groups take on this freedom to live their processes, they acquire the ability to interpret their own situation and what is happening around them. This ability is what is going to give them a minimum possibility of creating and making them able to preserve exactly this character of autonomy that is so important. ${ }^{10}$ After this brief presentation of the concept of subjectivity, we now begin to address the concepts of rhizome and tree, which allow to subsequently make an analogy between how nurses organize their work and the subjective issues involving them.

\section{THE CONCEPTS OF RHIZOME AND TREE AS A REFERENCE TO CONSIDER NURSING WORK}

One of the concepts of Deleuze and Guattari used in this work is "rhizome", which for the authors has an approximation to botany, but in a broader sense. In botany, a rhizome is a type of stem that some green plants have, which is characterized by horizontal growth, usually underground, but that may also have portions above ground. It can serve as an organ to store up energy, becoming tuberous, but maintaining a structure different from a tuber. ${ }^{12}$

Thus, the rhizome is more than a type of stem because it contemplates multiplicity. This multi- plicity can be, if we follow abstraction, a part of the stem with "the earth, the air, the animals, the human idea of soil, and the tree, which is not limited to pure materiality, but to the immateriality of an abstract machine that drags it; therefore, it is a concept that makes it at the same time ontological and pragmatic of analysis." 12:2-3

A rhizome has no beginning or end. It is not subject to a point nor to verticality and it is not exact. The rhizome is a set of vague elements, nomads, disorganized, and not of classes, presenting as principles the connection and heterogeneity, the multiplicity, asignifying rupture, and cartography. Thus, "any point of a rhizome can be connected to any other and should be so."13:15 The rhizome has no fixed points or orders, but has only several semiotic paths, states, and things, and nothing necessarily refers to the other thing. A rhizomatic analysis, therefore, seeks to "establish transversal connections between the layers and levels without trying to center them or surround them, but by crossing them, connecting them."10:322

Following the principle of asignifying rupture, a rhizome may be ruptured, and broken at any point, but it can start up again on one of its old lines, or on new lines. When this rupture occurs, the segment lines that form the rhizome explode into a line of flight, which can meet with elements that reorder the set and reconstitute the subject. ${ }^{13}$ Similar to a map, the rhizome is open and separable, and may be connected to any one of its parts or dimensions, and still be reversible and susceptible to receiving any kind of assemblies and liable to be (re)built by an individual or a social formation, such as a work of political action, for example. This analogy with a map can be attributed to the rhizome's principle of cartography.

Because it is a map, the rhizome is opposed to the decal, and includes multiplicity, which is denied by the decal, meaning that the decal, as a result of static reproduction of a condition, models and paralyzes the rhizome as a photograph, and from this record taken, it reproduces it infinitely without considering its modifications, multiplicities, and heterogenicity, without allowing openness to possible new conditions. The decal translates the map into an image, then organizes, stabilizes, and neutralizes the multiplicities according to its own axes of significance and subjectification. The decal no longer reproduces anything other than itself when it believes it is reproducing something else. Therefore, the decal can be dangerous if it reproduces from the map or 
from the rhizome only the impasses, the blockages, or points of structure. ${ }^{12}$

In opposition to the concept of rhizome, Deleuze and Guattari ${ }^{13}$ present the definition of the tree, which has the characteristics of articulation and hierarchy of decals. The tree inspires an image of thinking that mimics the multiple based on a superior, central unit. Thus, the arborescent models receive information from a superior unit and a subjective attribution of pre-established connections. For them, the tree may also include a rhizome, maintaining however a vertical structure at the same time from which sprout other horizontal and multifaceted structures. "There are always tree structures and roots in the rhizome, but rhizomes also sprout from the trees." 12:8

So the rhizome and the tree can represent the nursing work. At first glance, it seems impossible and even illogical, but after further consideration, the proper analogy will be presented, leading the reader to reflect on nursing work from the perspective of rhizomatic thought articulated to issues of subjectivity.

\section{NURSING WORK AND THE NON- IMPLEMENTATION OF THE NURSING PROCESS}

In an attempt to bring together the aforementioned concepts, one can think of nursing work as a tree structure and at the same time a rhizomatic one. This is justified because nursing makes use of a body of verticalized and structuring knowledge, less flexible, which may be represented by the clinical work and by the management in health, for example. This knowledge has its due importance and cannot be replaced, being, at the most, improved in order to ensure greater quality in the care provided. On the other hand, nursing as a science needs to be thought from a perspective that does not follow a linear or unidirectional reasoning, giving support to ambivalence, diversity, and even chaos, whose characteristics allow new understanding of the same object outside of a rigid and standardized structure.

Thus, our intention in this study was to think of nursing work from this larger perspective in which the difficulties that emerge from practice and hinder the implementation of the NP are heterogeneous and connected, multiple and mapped, and thus in line with the principles of the rhizome. On the other hand, the NP itself can be represented by a more vertical structure when considering it from the clinical perspective, since, for its complete development, knowledge of anatomy, biology, pathology, and pharmacology are required, among others. Figure 1 below seeks to introduce to the reader the nursing work structure from the theoretical perspective of Deleuze and Guattari.

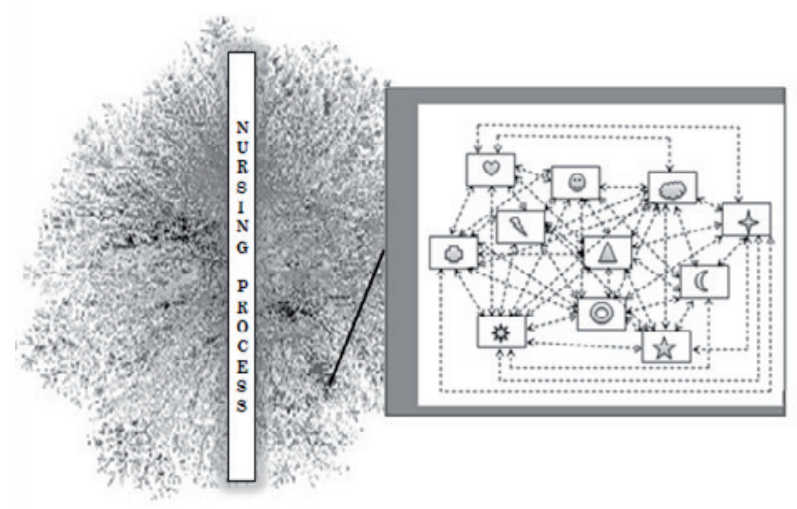

Figure 1 - Nursing work

This figure aims to represent the nursing work, which is permeated by a body of scientific knowledge called the nursing process. The NP as a scientific method that guides the nursing work gathers knowledge based on the more vertical, objective and perhaps inflexible clinical model. So that is why here it is equated with the tree structure described by Deleuze and Guattari.

On the other hand, the rhizome can be represented by the plot of lines seen in this figure that form a set of aspects leading to difficulties in the implementation of the NP, which is a network of factors that interfere in the work of nurses when they depend on external stimulus or even on its subjectivity and the subjectivity of other workers. This plot, when viewed in more detail, shows the principles of the rhizome, such as the heterogeneity and interconnectivity, multiplicity, and cartography.

In the figure, the elements are represented by heterogeneous symbols, not specifically defined, but that perhaps represent the nurse's family and work environment, culture and institutional organization, the relationship of the nurse with the multidisciplinary and nursing teams, as well as with the different managers, patients, family members, and undergraduate and graduate students. It can also refer to the relationship with the material resources and with the possibility of the nurses' professional development, to their wages, to the relations of power and resistance, along with 
their feelings, emotions, sensitivity, desires, (de) motivations, among others. Just as the rhizome can be underground and not noticed at first glance, these characteristics may also be veiled during nursing work.

The heterogeneity represented by this range of elements of origin and distinct nature is reinforced by the inexistence of a hierarchical order or of importance for the positive or negative interference at work. Moreover, it goes beyond the idea that the difficulties of implementing the NP are only assigned to clinical knowledge (or the lack thereof), but they go beyond their own environment and the knowledge that the job entails.

Thus, it is considered that this is not just a matter of adapting the stages of the NP to the everyday tasks of nurses. It is necessary to view the work itself under the influence of a multiplicity and heterogeneity of factors and paths crossed, having the understanding that they can act alone, not necessarily depend on each other, or even continue interfering in the work even if there is a rupture of one or a few of them. This perspective proposed conforms to the rhizomatic thinking that makes room to recognize, accept, and promote multiple discourses within nursing, challenging the status quo, while at the same time promoting alternatives and paths of transformation. ${ }^{14}$

It is relevant to think that all the elements cited can already be the subjectivity of the nurses and other professionals from the nursing staff in their institutional group or as a professional category and, if not that, they can shape new individual subjectivities from those who choose to join the profession. So if there is an awareness of the interference of all the elements that are present in the work of nurses and members of the nursing team, then one can think of theoretically based strategies to overcome the obstacles to the implementation of the NP and work directly on the determinants of what is called capitalistic subjectivity whose effects may be felt by nursing as a whole. But are nurses aware of this?

One of the alternatives for dealing with this subjectivity imposed by capitalism are the processes of singularization already mentioned, among which we can highlight the "molecular revolution". It concerns a system of contestation of capitalistic subjectivity based on the questioning of everyday life, of the reactions of refusal to work in its current form (capitalistic) in order to create mutations in the portions of conscious and unconscious subjectivity of individuals and social groups. Therefore, the molecular revolution is to produce the conditions not only of a collective life, but also the incarnation of life for itself, both in the material field and in the subjective field. ${ }^{10}$

With regard to nursing work, a repeated complaint of lack of time to implement the NP, for example, was found both nationally and internationally. This problem can be best discussed from the perspective of the processes of singularization in which nurses (in a group action in the same inpatient unit or institution) may question the current routine of work and its organization and proceed to deny doing what often can or should be done by other members of the nursing/health team, not wasting their time with activities that are the legal and moral responsibility of others (secretarial work, telephone operator, etc.). This could contribute so that the specific work of nursing be prioritized and this way establish a new routine that includes the implementation of NP dynamically by shifts. Is this usually done? Can it be said that nursing produces processes of singularization?

Therefore, at the moment when nurses think of their work and check what is the logic that feeds it (acting from the perspective of quantitative production, acting coerced by colleagues of the same class/professional category or of others, pressure from the boss or from the institutional molds, by the plans and work pace imposed), it will be possible to transform it. By becoming aware of this, perhaps, nurses will be able to stop adapting to the logic that they have been adapted, whether by their own desire, for convenience, obligation or even as a matter of survival in the workplace (the unit or institution).

The attitude of the nursing workers toward a single organization may come in the sense of creativity, the expression of their singularity, rather than subjection to institutionally molded subjectivity, which means the mere reproduction of decals. It is a fact that there is a prescribed organization that is independent of the workers, but that can be modified by their interaction in the work process; and there is also another organization that is prescribed by the workers themselves when they think about their work. In this scenario, their actions and thoughts give life to the real organization. ${ }^{15}$

At the time workers think/design their work, their action toward the subject of care is in a way planning, systematizing, building, and evaluating the care, which can be considered or- 
ganizing their work. It is in the space between the prescribed organization of the work and the action actually carried out that the subjectivity of workers shows up with more force, despite being almost always still in an invisible, incipient form. It is the space in which they can give themselves entirely to the process as a participating, decisive, creative subject, with autonomy in doing. ${ }^{15}$ But a question arises in relation to this issue: Do nursing workers have freedom to live out their processes? Do they have the proper autonomy to be the mediator of their own work?

If nursing workers view themselves as participating and determining agents of their own work, they will have the autonomy to shape what they do, with the responsibility of always developing the best that implies in qualified care, and at the same time they do not necessarily depend on an institutional framework or the use of a predetermined routine. Nurses, therefore, building a line of flight, which means inventing a path to develop their work differently from the capitalist production line and organized by the institution or health system, can and should be empowered to seek knowledge that will help them think better and do their work in a way to create viable alternatives for a more effective care of the patients under their responsibility.

More specifically in relation to the NP, what is meant is that the nurses do not need to wait for the managers of the hospital or even for the health system to determine and impose the execution and registration of this method to begin to better develop it. Nurses can create their own modes of reference, their cartographies, and invent their praxis so as to create gaps in the system of dominant subjectivity, not reproducing an aspect that perhaps belongs to the culture of the institution.

Therefore, they can create their paths to build a routine that is feasible for implementing the NP, provided they have the desire to do so. "The common thread between the different processes of singularization is a becoming differential that refuses capitalistic subjectivity. This can be felt from the warmth in the relationships, by a certain way of wishing, by a positive affirmation of creativity, by a desire to love, by a desire to simply live or survive by the multiplicity of these desires. We need to make room so that this can happen. The desire can only be lived in vectors of singularity." 10:56

Thus, it can be noticed that the desire is another important process of individuation, capable of promoting revolutionary micro-processes. It permeates the social field in immediate practices and in ambitious projects and can be defined as a myriad of desires, since the desire to live, to create, to love, and even to invent another society and other perceptions of the world and notions of values. Therefore, "desire is always the way of producing something; desire is always the way to build something." 10:261 Is there really a desire to do differently? Or has desire, as stated by Guattari, already been castrated by others, being no longer expressed by nursing workers?

Since desire produced something, Guattari and Deleuze use the expression "desiring machine" as a metaphor to refer to it, considering the capitalistic context that all their writing is related. Following this perspective, desire has different possibilities of assemblage and is not summarized to schemes of psychoanalysis, nor can it be equated with an animal instinct, an organic impulse, or brute force. Desire is neither an undifferentiated energy nor a function of disorder. Therefore, it cannot be regarded as something nebulous, disorganized, and that needs to be castrated or disciplined. Desire is shown to be connected to different elements that surround it, which can range from the family to the cosmos. ${ }^{10}$

However, the desire to think also requires some thought considering that it is not a force that in itself is going to build an entire coordinated universe. Like any machine, desire can also get paralyzed and blocked, running the risk of destroying itself. The concept of desire in the social field tends to question the idea that desire and subjectivity are centered on the individuals and that they would result from the interaction of individual facts on the collective plane. Guattari takes as a basis the idea of a process or collective system of building desire and subjectivity that in some circumstances or in some social contexts can be individualized. In the case of the NP, how can a desire to carry it out turn into viable actions to implement it?

All movements of singularity that maximize the ways of existing in an authentic way clash against "the wall of capitalistic subjectivity", and it is necessary to build another logic that is "different from the usual logic, to be able to make it possible for this wall to coexist with the image of a goal that a strength would be able to perforate it".$^{10: 172}$ This must be done, even knowing how much this wall can be terrible and that its demolition implies in coming up against difficult and organized ways, and at the same time continue to develop territories where people feel good. Failure to preserve 
these two dimensions causes us to run the risk of leaving the power to the state, which will control everything and everyone, leading us to a situation of impotence. ${ }^{10}$ "We present ourselves to do something, and if it works, fine; if it does not work, that is also fine, because we may eventually be able to do it in another way, at another time. On the other hand, it is very important that this structure of parameters exists so as to monitor issues as they appear, where one can express these kinds of collective investment of desire, where together we can assess the consistency of these different projects." 10:147 Therefore, we agree with Deleuze and Guattari when they claim that a dialogue among minorities can have a greater impact than a simple agreement between oppressed groups. This dialogue can lead to a more positive, more offensive attitude that will consist of a questioning of the very purpose of modern societies.

\section{CONCLUSIONS}

In summary, as shown by the philosophical framework used, subjectivity is constructed internally and externally and is related to a heterogeneity of factors that are socially and historically determined. Some behaviors or attitudes revealed in the practice of nursing workers can often be related to everything they learned in their life since childhood and also during the years of training and professional practice. Hence, it is difficult to change habits that are already unconsciously engrained in these workers, at least without there being a questioning that awakens their awareness to this, thus bringing up a reflection on why it is done a certain way, what led them to act that way, and what they expect from their work.

To encourage the worker to exercise the routine can then contribute to the transformation of their praxis, helping them understand what determines or influences their actions. However, this does not mean it is a way of solving all the objections arising at work. It is only one way among many other possible ones. It is only the building of a line of flight that makes it possible to invent other ways of thinking and doing the work, modifying a small portion of the collective subjectivity, which can be achieved by encouraging activism of the worker in the realization of the praxis.

The proposition of studies that promote group discussions and reflections on the work of nursing can be a strategy for the collective construction of desire to transform the practice, taking into account the alliance between differ- ent individual subjects (who can be the nurses, technicians, nursing assistants, undergraduate and graduate students), which agrees with the design of singularization used by Guattari and Deleuze.

This singularization does not usually occur at the individual level. It is a process that acts on the collective level and develops with it, just as capitalism, which is not what it is because only one individual adopts its conceptions. It is what it is precisely because it has a collective reach that influences the relations of life and work on a planetary scale.

Often, attempts of singularization are difficult, problematic, and end up being aborted. But despite the precariousness and failures of these attempts, despite the dispersion, the anguish, the madness, and the misery, they are breaking with the production of capitalistic subjectivity. They trigger processes of reappropriation of thinking and doing, leading to the transformation of subjects and their practices, which can interfere in the production of other theories, sensitivity, motivation, and understanding of and for the work.

Being sensitive to the dimension of subjectivity in nursing work, therefore, can help in trying to understand individuals, their conflicts, their bonds with themselves and with work, as well as the production and insertion of each person in the nursing/health team and worldwide. Furthermore, the problem of subjectivity and its influence on the work process can contribute to the analysis of the reasons why the different phases of the NP are not carried out and why it is not implemented by nurses in various contexts where their nursing work takes place, considering that a manifestation of desire to transform reality depends on them. Thus, a rhizomatic vision about the work itself can make it so that nursing understands what it builds and what constitutes its subjectivity, opening the possibility of keeping it capitalistic or not.

\section{REFERENCES}

1. Bordinhão RC. Processo de enfermagem em uma unidade de tratamento intensivo à luz da Teoria das Necessidades Humanas Básicas [dissertação]. Porto Alegre (RS): Universidade Federal do Rio Grande Sul. Programa de Pós-Graduação em Enfermagem; 2010.

2. Garcia TR, Nóbrega MML. Processo de enfermagem: da teoria à prática assistencial e de pesquisa. Rev Enferm Esc Anna Nery. 2009 Jan-Mar; 13(1):188-93.

3. Barra DCC, Dal Sasso GTM, Monticelli M. Processo de enfermagem informatizado em unidade de 
terapia intensiva: uma prática educativa com enfermeiros. Rev Eletr Enferm [online]. 2009 [acesso 2012 Abr 25]; 11(3). Disponível em: http:/ / www.fen. ufg.br/revista/v11/n3/v11n3a15.htm

4. Conselho Federal de Enfermagem (BR). Resolução COFEN n. 358/2009. Sistematização da assistência de enfermagem e a implementação do processo de enfermagem em ambientes, públicos ou privados, em que ocorre o cuidado profissional de Enfermagem. [acesso 013 Jun 17]. Disponível em: http://novo. portalcofen.gov.br/resoluo-cofen-3582009_4384. html

5. Backes DS, Esperança MP, Amaro AM, Campos IEF, Cunha ADO. Sistematização da assistência de enfermagem: percepção dos enfermeiros de um hospital filantrópico. Acta Sci Health Sci. 2005; 27(1):25-9.

6. Amante LN, Anders JC, Meirelles BHS, Padilha MI, Kletemberg DF. A interface entre o ensino do processo de enfermagem e sua aplicação na prática assistencial. Rev Eletr Enferm [online]. 2010 [acesso 2012 Abr 21]; 12(1). Disponível em: http:/ / www.revistas.ufg.br/index.php/fen/article/ view/9538/6608

7. Fernández-Sola C, Granero-Molina J, AguileraManrique G, Peredo-de MHG, Castro-Sánchez AM, Pérez AG. Strategies to develop the nursing process and nursing care plans in the health system in Bolivia. Int Nurs Rev. 2011 Set; 58(3):392-9.
8. Juntilla K, Salanterä S, Hupli M. Perioperative nurses' attitudes toward the use of nursing diagnoses in documentation. J Adv Nurs. 2005 Nov; 52(3):271-80.

9. Jansson I, Pilhamar E, Forsberg A. factors and conditions that have an impact in relation to the successful implementation and maintenance of individual care plans. World views on EvidenceBased Nursing. 2011 Jun; 8(2):66-75.

10. Guattari F, Rolnik S. Micropolítica: Cartografias do desejo. 11 ${ }^{\mathrm{a}}$ ed. Petrópolis (RJ): Vozes; 2011.

11. Lunardi-Filho WD. O mito da subalternidade do trabalho da enfermagem à medicina. $2^{\mathrm{a}}$ ed. Pelotas (RS): Universitária UFPel; 2004.

12. Cabral C, Borges D. Rizoma: uma introdução aos mil platôs de Deleuze e Guattari. Rev Critério [online]. 2005 [acesso 2012 Mai 21]; 1(4): Disponível em: http://www.academia.edu/482209/Rizoma_uma_ introducao_aos_Mil_Platos_de_Deleuze_e_Guattari

13. Deleuze G, Guattari F. Mil platôs: capitalismo e esquizofrenia. São Paulo (SP): editora 34; 2004.

14. Holmes D, Gastaldo D. Rhizomatic thought in nursing: an alternative path for the development of the discipline. Nurs Philosophy. 2004 Nov; 5(3):258-67.

15. Azambuja EP, Pires DEP, Cezar-Vaz MR, Marziale MH. É possível produzir saúde no trabalho da enfermagem? Texto Contexto Enferm. 2010 OutDez; 19(4):658-66. 